\title{
LYMPHATIC VESSELS IN HEALTH AND DISEASE
}

\author{
Cristina T. Kesler, Shan Liao, Lance L. Munn, and Timothy P. Padera* \\ E. L. Steele Laboratory, Department of Radiation Oncology, Harvard Medical School and \\ Massachusetts General Hospital, Boston, MA 02114
}

\begin{abstract}
The lymphatic vasculature plays vital roles in tissue fluid balance, immune defense, metabolism and cancer metastasis. In adults, lymphatic vessel formation and remodeling occurs primarily during inflammation, development of the corpus luteum, wound healing, and tumor growth. Unlike the blood circulation, where unidirectional flow is sustained by the pumping actions of the heart, pumping actions intrinsic to the lymphatic vessels themselves are important drivers of lymphatic flow. This review summarizes critical components that control lymphatic physiology.
\end{abstract}

In normal tissues, fluid and plasma elements from the systemic blood circulation are exchanged at the capillary level to bring nutrients to cells and to eliminate waste. A critical function of lymphatic vessels is to return excess fluid back to the circulation. Fluid is initially collected by a lymphatic capillary plexus (the initial lymphatics) and transported to collecting lymphatic vessels in the form of lymph (Figure 1). The collecting lymphatics have circumferential smooth muscle coverage and luminal valves that propel and maintain unidirectional flow of lymph fluid. Along the way, the lymph, which is rich in antigens and immune cells, drains through lymph nodes, thereby allowing for efficient organization of immune responses. Antigen is picked up by dendritic cells in peripheral tissues and transported via lymphatics to lymph nodes where lymphocytes survey for specific antigens. Thus, lymphocytes can maintain immunocompetence by circulating from one lymph node to another rather than to each individual tissue of the body. Digested lipids are also absorbed by virtue of mesenteric lymphatic transport (reviewed in ${ }^{1}$ ).

Disruption of lymphatic drainage leads to disabling and incurable lymphedema. Lymphedema, or lymphatic insufficiency, is characterized by painful regional swelling as fluid accumulates interstitially. Over time, lymphedema results in disfigurement and compromised immune defenses in the affected region. Congenital diseases, parasitic infections, lymphadenectomy and post-surgical radiotherapy in cancer patients are main causes of impaired lymphatic function. Moreover, malignant tumors can directly alter surrounding lymphatic vessels, allowing cancer cells to invade and be transported via the lymphatic drainage to the lymph node.

\section{LYMPHATIC VESSEL DEVELOPMENT}

Lymphatic vessels begin to form in utero around week 6-7 in humans and embryonic day E9.5-10.5 in mice, after the cardiovascular system is established and functional. Endothelial cells (ECs) derived from the anterior cardinal veins commit to the lymphatic lineage to form lymph sacs. Lymphatic vessels sprout from these lymph sacs in a process known as lymphangiogenesis. These new vessels merge with separate lymphatic capillary networks to

*Correspondence: tpadera@ steele.mgh.harvard.edu.

Conflict of Interest Statement: The authors have no conflicts of interest. 
form a lymphatic capillary plexus (reviewed in ${ }^{2}$ ). As the lymphatic vascular tree expands, connections to blood vessels are lost, except where lymph returns to the blood in the subclavian veins. Expression of a non-receptor cytoplasmic tyrosine kinase $s y k$ (spleen tyrosine kinase) and a signal-transducing adaptor protein $\operatorname{slp} 76$ ( $\mathrm{SH} 2$ domain-containing leukocyte protein of $76 \mathrm{kDa}$ ), in ECs as well as in circulating hematopoietic cells, is critical to the separation of blood and lymphatic vessels. ${ }^{3,4}$ Loss of these mediators results in abnormal connections between lymphatic and blood vessels during embryogenesis. ${ }^{4}$

Commitment to the lymphatic lineage begins with the expression of prox 1 (prospero-related homeobox-1) by ECs on the dorsal side of the cardinal vein. Triggered by expression of sox 18 (SRY-related HMG-box 18), prox 1 expression provides the first indication of lymphatic competence and is indispensable for lymphatic vessel development. ${ }^{5,6}$ It is initially expressed in mice at E9-9.5. Together with venous EC fate regulator protein COUPTFII (chicken ovalbumin upstream promoter transcription factor 2), the Prox 1 transcription factor upregulates numerous lymphatic-specific genes while suppressing certain blood vessel markers. ${ }^{5}{ }^{7}$ Lyve1 upregulation also provides an early indication of lymphatic competence, though its expression is non-essential for lymphatic development. ${ }^{8}$

Another requirement for a functioning lymphatic network is expression of the forkhead transcription factor FoxC2. FoxC2 protein regulates the expression of numerous genes involved in the specification of initial versus collecting lymphatic vessel phenotype. During development, FoxC2 works together with Prox 1 and fluid flow to form the lymphatic valves, which are essential for collecting lymphatic vessel function. ${ }^{9}$ Deletions or inactivating mutations of Fox 2 cause an irregular distribution of smooth muscle cells (SMCs) along the collecting vessels and prevent valve formation. ${ }^{9}, 10$ Mutations in Fox $C 2$ are implicated in a congenital form of lymphatic insufficiency known as the lymphedema distichiasis syndrome. ${ }^{11}$

Numerous growth factors cooperate in the development and maintenance of lymphatic vessels. They do so by binding cognate receptors located on the surfaces of lymphatic endothelial cells (LECs). This association activates (or suppresses) enzymatic activity that transduces signals to alter cellular biological processes. Two major ligand-receptor pathways that govern LEC biology are the vascular endothelial growth factor (VEGF)-VEGF Receptor (VEGFR) pathway and the angiopoietin (Ang)-TIE(tyrosine kinase with Ig and EGF homology domain) axis. Lymphangiogenesis and sprouting of the first Prox1-positive LECs during embryogenesis are driven by VEGF-C and VEGF-D-mediated activation of VEGFR-2 and VEGFR-3. These players remain heavily involved in lymphatic maintenance during adulthood. ${ }^{12,13}$ Ang molecules stimulate postnatal vessel growth, remodeling and maturation. ${ }^{14-16}$ A homozygous knockout of Ang-2 (ang- $2^{-/-}$) produces a strong mesenteric lymphedema phenotype in newborn mice. ${ }^{14}$ In addition, the transmembrane ligand ephrinB2 is critical for remodeling of the primary lymphatic capillary plexus into a hierarchical vessel network. EphrinB2-1- mice display defective remodeling of the capillary plexus and lymphatic hyperplasia. These vessels also lack intraluminal valve formation. ${ }^{17}$

CD11b+ macrophages play important roles in inflammation- and tumor-induced lymphangiogenesis. Activated CD11b+ cells are capable of forming tube-like structures in vitro that display lymphatic markers including LYVE-1, Prox-1 and podoplanin. ${ }^{18,} 19$ $\mathrm{CD} 11 \mathrm{~b}+$ macrophages also produce VEGF-C and VEGF-D, allowing them to stimulate lymphangiogenesis within the local lymphatic vessel network. ${ }^{18,20-22}$ Expression of lyve1 and vegfr 3 by CD11b+ cells has been observed in the mouse conjunctiva, with a higher number of VEGFR3-positive cells appearing in inflamed eyes. ${ }^{19}$ Furthermore, expression of vegfr 3 by $\mathrm{CD} 11 \mathrm{~b}+$ cells is implicated in tumor-mediated chemotaxis of activated 
macrophages by VEGF-C-expressing tumors and may contribute to tumor metastasis. ${ }^{19,22,23}$

The structural composition of mature lymphatic vessels is important for moving interstitial fluid and lymphocytes through the lymphatic vessel lumen. Discontinuous, button-like junctions connect LECs of the initial lymphatics to one another. These buttons facilitate fluid and lymphocyte entry into the lymphatic system by allowing transport between LECs. They are composed of adherens junction protein VE-Cadherin, tight junction proteins claudin-5 and zonula occludens-1 (ZO-1), tight junction-associated Ig-like transmembrane proteins endothelial cell-selective adhesion molecule (ESAM), junctional adhesion molecule-A (JAM-A), and PECAM-1/CD31. ${ }^{24}$ The LECs of the collecting lymphatics, which function to transport the drained fluid and cells over long distances, form continuous zipper-like connections without the button-like openings. Zippers are comprised of the same adhesion molecules as the buttons of the initial lymphatics, indicating that the key difference between buttons and zippers lays in the morphology of the individual LECs and the organization of a common constellation of junctional proteins. ${ }^{24-26}$

\section{FLUID HOMEOSTASIS AND LYMPHATIC PUMPING}

Lymphatic networks are found in nearly all vascularized tissues, with the exception of bone marrow and the central nervous system (though some connections between the cerebrospinal fluid and lymphatics exist). ${ }^{27}$ Lymph collection occurs in the initial lymphatic vessels (Figure 1), which are structures comprised of a single layer of overlapping endothelial cells, typically without associated SMCs. As the vessels carry lymph back toward the blood circulation, the amount of SMC coverage increases. This increased coverage identifies the pre-collecting and larger collecting lymphatic vessels. SMC coverage is periodically interrupted by intraluminal valves, which are composed primarily of ECs and matrix. ${ }^{28,} 29$

Multiple factors drive lymphatic pumping. Lymphatic transport is driven externally by arterial pulsations, skeletal muscle contractions, and in the mesentery, by smooth muscle contractions. Transport is also autonomously driven by contractions that are unique to the collecting lymphatic vessels (Figure 2, Movie 1). These vessels are composed of individual pumping units known as lymphangions, each of which has an inlet and an outlet valve. These valves, along with the SMCs that line the collecting lymphatics, represent the main mechanisms by which lymphatic contractions maintain unidirectional flow of lymph. ${ }^{30}$

These autonomous contractions are critically modulated by extrinsic and intrinsic forces, which include lymph formation rate, local compression due to muscle movement, local interstitial fluid pressure, lymphatic flow rate and inflammatory mediators. One critical regulator of autonomous lymphatic contraction is nitric oxide (NO). NO is responsible for the reduction in tone in the lymphangion during the relaxation phase of its contraction. NO production inhibits the contraction by depolarizing ATP-sensitive $\mathrm{K}(+)$ channels located on the plasma membranes of SMCs. ${ }^{31} \mathrm{NO}$-induced relaxation allows for diastolic filling of the lymphangion and thus prepares the vessel for its next contraction. 32,33

NO is primarily produced by three isoforms of nitric oxide synthase (NOS), the most relevant of which is endothelial NOS (eNOS). eNOS is expressed by the LECs of the collecting lymphatic vessels and is critical for VEGF-C-mediated lymphangiogenesis. ${ }^{34,} 35$ eNOS expression and NO production are higher in the lymphatic bulb surfaces of the valve relative to the tubular portions. ${ }^{36,37}$ It has been predicted that during phasic pumping, the shear forces from fluid flow activate eNOS in the endothelium to produce NO. ${ }^{28,33-36,38-40}$ While the total NO concentration is critical, temporal and spatial gradients of NO are fundamental to its action on vessels (Figure 2). ${ }^{41,} 42$ The short, active half-life of NO in vivo produces these spatial and temporal gradients. In order to produce a lymphatic contraction, 
NO is released in response to the elevated shear force caused by a contraction from an area near the valve during the systolic phase. ${ }^{36}$ This NO release starts the diastolic relaxation necessary for lymphangion filling and the next cycle of contraction. Using mathematical simulations, it has been shown that the ability for phasic lymphatic contractions to be selfsustained is very sensitive to the half-life of the effector molecules. In this context, NO seems ideally suited to this purpose. ${ }^{43}$

The impact of $\mathrm{NO}$ on lymphatic pumping has been extensively studied using numerous methods that modulate NO production. Pharmacological blockade of eNOS using inhibitors - $\mathrm{N}^{\mathrm{w}}$-Nitro-L-Arginine (L-NAME), $\mathrm{N}^{\mathrm{G}}$-monomethyl-L-arginine (L-NMMA), $\mathrm{N}^{\mathrm{W}}$-nitro-Larginine (NOLA) or the non-specific inhibitor methylene blue-in mesenteric and thoracic duct vessels ex vivo results in an acute increase in the pumping frequency that is accompanied by a decrease in lymph fluid velocity. ${ }^{33,40,44-46}$ These findings are supported in vivo, where L-NMMA treatment produces an increase in the frequency of contractions of the afferent vessel to the popliteal lymph node. ${ }^{30}$ However, the NO effects on pumping are context-dependent and influenced by experimental conditions. ${ }^{38,39}$ For instance, Koller et. al. report that blockade with L-NAME prevents the increase in lymphatic contraction frequency associated with lymph flow in vessels afferent to the iliac lymph node in rats. ${ }^{39}$

Chronic depletion of eNOS using an eNOS knockout mouse (eNOS-I-) results in decreased lymph flow. ${ }^{34}$ eNOS-/- also produces a decrease in contraction strength corresponding with an increase in the frequency of contractions in the afferent lymphatic vessels of the popliteal lymph node. ${ }^{30}$ The prevailing model suggests that when eNOS is blocked, the lymphatic segment contracts more frequently to maintain lymphatic flow appropriate for the existing level of preload. ${ }^{30,33,34,40}$

There is a somewhat paradoxical increase in lymphatic diameter with eNOS inhibition in vivo, indicating that other regulatory molecules are involved with the integrated control of lymphatic pumping. ${ }^{30,} 38,47,48$ For instance, arachidonate metabolites are well known mediators of spontaneous contractions. ${ }^{49,50}$ The cyclooxygenase inhibitor aspirin and inhibitors of thromboxane synthase suppress phasic contractions ex vivo. ${ }^{48,}{ }^{49}$ Acetylcholine induces NO-dependent lymphatic vessel relaxation that is antagonized by atropine but not by cyclooxygenase inhibitors, indicating a separate mechanism for muscarinic influence. ${ }^{51,52} 5$-hydroxytryptamine (5-HT) modulates the rate of lymphatic pumping by decreasing the frequency of contractions induced by vessel perfusion of isolated guinea pig mesenteric vessels through actions on lymphatic SMCs. ${ }^{53}$ Working in the opposite direction, histamine increases the frequency of contractions while decreasing their amplitude. ${ }^{54}$ Activated macrophages have also been implicated in the relaxation of lymphatic vessels through generation of NO and prostaglandins. ${ }^{55}$ Extracellular glucose and intracellular glucose transporters increase pumping frequency and induce constrictions of the rat thoracic duct. ${ }^{47}$ VEGF-C increases lymphatic pumping of rat mesenteric vessels in vivo through VEGFR3, which results in release of intracellular $\mathrm{Ca}^{2+}$ within LECs and activation of eNOS. ${ }^{13,56}$ Pharmacological inhibition of Rho kinase in SMCs of afferent lymph vessels results in vessel dilation and cessation of pumping ex vivo. ${ }^{57}$ Pharmacological inhibition of myosin phosphatase produces vessel constriction with reduced lymphatic pumping frequency ${ }^{57}$ The identification of new molecules that impact lymphatic pumping is an active area of research. These molecules may provide new pharmacological targets for treatments of lymphatic insufficiency.

LECs function under low oxygen tension $(8-35 \mathrm{mmHg})$ compared to surrounding tissue and blood vessels. The mean $\mathrm{pO}_{2}$ levels in lymphatic capillaries, collecting lymphatic vessels and thoracic ducts rise sequentially from $\sim 8$ to $\sim 20$ to $\sim 35 \mathrm{mmHg}$, respectively. The reduced oxygen availability in lymphatics promotes an increase in NO bioavailability. ${ }^{31}$ 
Furthermore, the lower $\mathrm{pO}_{2}$ levels in lymphatics relative to surrounding tissue indicates that the metabolic activity and oxygen consumption of the collecting lymphatic vessels is high, emphasizing the active nature of many processes of these vessels. ${ }^{58}$

Another isoform of NOS—inducible NOS (iNOS) — is expressed predominantly by surrounding immune cells and is not expressed in LECs under physiological conditions. Unlike $\mathrm{eNOS}^{-/-}$mice, $\mathrm{iNOS}^{-/-}$mice show no reduction in the strength of lymphatic contractions under normal conditions. However, iNOS does attenuate contractions during inflammation by overwhelming the critical temporal and spatial $\mathrm{NO}$ gradients produced by eNOS in LECs. Induction of cutaneous inflammation in mice results in infiltration of iNOSexpressing bone marrow-derived cells, which produce elevated levels of NO. Knockdown of iNOS in these cells allows the NO gradients to be maintained by eNOS function and prevents attenuation of lymphatic contractions, underscoring a mechanism by which immune cells alter lymphatic fluid flow. ${ }^{30,40}$

\section{LYMPHATIC FUNCTION AND THE IMMUNE RESPONSE}

Collected lymph fluid is rich in antigens and humoral factors that are either drained from surrounding tissues or are constitutively present in lymphatic vessels. This antigen and immunocyte-rich fluid is interrogated as it passes through the lymph node (LN) on its way back to the systemic circulation. In this manner, the antigen and antigen presenting cells (APCs) draining from peripheral tissues are efficiently concentrated in the draining LN. During the normal homeostatic state, the cells that enter the LN from the lymphatics are primarily dendritic cells (DCs) and memory T cells. ${ }^{59,60}$ DCs constantly sample selfantigens and migrate to LNs where they maintain an immature status characterized by lowlevel expression of co-stimulatory molecules. They control self-reactive $\mathrm{T}$ cell activity by inducing self-tolerance through anergy and clonal deletion. In this way, LNs function as additional niches alongside the central tolerance mechanisms present in the thymus to generate peripheral tolerance. Non-hematopoietic stromal cells that are present in the LN (e.g. LECs or fibroblastic reticular cells (FRCs)) also promote tolerance by their expression of peripheral tissue antigens. ${ }^{61-63}$ Foreign antigens, however, elicit profound immune responses within the LN upon their presentation by activated dendritic cells, among other mechanisms.

\section{The Lymph Node}

Functional lymphatic vessels are required for the maintenance of the LN micro-architecture, which supports optimal interactions between antigen presenting cells (APCs) and rare antigen-specific lymphocytes ${ }^{64-67}$ (Figure 3). In the lymph node the primary follicles are composed of B cells with follicular DCs located in the cortex of the lymph node. T cells and DCs distribute in the paracortical area. The majority of lymph node macrophages reside in the marginal sinus and medullary cords. LECs surround the LN and concentrate in the medulla and sinus area.

The compartmentalization of cells in LNs is orchestrated by lymphoid chemokines. Chemokines CCL21 and CCL19 recruit and direct the distribution of chemokine receptor CCR7-expressing cells, mostly T cells and DCs, while CXCL13 attracts CXCR5-expressing B cells. A lipid signaling molecule, sphingosine-1-phosphate (S1P), along with its receptor, facilitates the egress of lymphocytes from LNs into efferent lymphatic vessels. ${ }^{68,} 69$ Blood vessels enter the lymph node from the hilum, run through the medulla and branch within and distribute throughout the cortex. In the paracortex, blood vessels specialize into high endothelial venules (HEVs), which facilitate lymphocyte homing from systemic circulation to LNs. $^{70,71}$ 
The LN conduit system connects the lymphatic sinus with the walls of the blood vessels and enables the incoming factor(s) from the lymph to move rapidly into the paracortical $\mathrm{T}$ cell area. ${ }^{72-74}$ The conduit system is implicated in providing physical support required for the rapid initiation of an adaptive immune response after immunization. Soon after immunization, a special subset of conduit DCs rapidly take up and process free antigen moving along the conduit. However, large antigens and microbial particles cannot access the $\mathrm{LN}$ via this conduit system. These particles enter the $\mathrm{LN}$ sinus where they are sampled by macrophages and B cells. ${ }^{75-77}$

Upon activation in the tissue, DCs rapidly migrate to LNs and initiate cell responses within hours of antigen presentation. ${ }^{78}$ DC entry into the peripheral lymphatics is CCR7-

dependent. ${ }^{79}$ The migration of activated DCs towards the T cell zone in the draining $\mathrm{LN}$ also relies on CCR7, which is orchestrated by CCL21 and CCL19 expressed by HEVs and FRCs. ${ }^{80,} 81$

\section{Inflammation}

A fine-tuned inflammatory response generates an immune reaction to foreign antigens while preventing overt reactions to self-antigens. The LN structure undergoes dramatic changes following antigen activation, including angiogenesis and lymphangiogenesis, decreased expression of genes contributing to peripheral $\mathrm{LN}$ addressin (PNAd), and decreased chemokine production of CCL21 and CXCL13. ${ }^{64,} 65,82-86$ These temporary changes in the LN hinder naïve T-cell and DC access and their interactions while enhancing the ability of effector cells to leave the $\mathrm{LN}$ and prevent pathological immune-mediated damage in the LN. Viral infection and an immune-stimulant known as polyinosinic:polycytidylic acid increases FRC suppression of the bystander CD8 T cell responses. ${ }^{86,87}$ However, disruption of lymphatic vessel or their autonomous contractions impairs fluid drainage and, thus, the body's ability to activate an immune response to a pathogen, which leads to persistent infection. ${ }^{64,} 88-92$ During clinical lymphedema, immune cell accumulation and impaired immune response are also frequently observed. ${ }^{93}$

During acute inflammation, lymphangiogenesis occurs in the area of inflammation and the draining LN. B cells contribute heavily to LN lymphangiogenesis in response to inflammation. ${ }^{64,}$ 82, 94 In LPS-induced peritoneal inflammation, macrophages promote lymphangiogenesis by expressing multiple lymphangiogenic growth factors such as VEGF and VEGF-C. ${ }^{18,}$, 95, 96 However, changes to lymphatic drainage during lymphangiogenesis appear to depend on the antigen and the site of immunization. Lymphatic drainage is reduced in response to oxazolone skin painting-triggered inflammation, as well as when lipopolysaccharide is applied in a peritoneal model. However, lymph transport increases when complete Freund's adjuvant is applied in the foot pad of the mouse. ${ }^{64,94,97}$ Moreover, gene expression patterns in LECs during inflammation are stimulus-dependent. ${ }^{98}$

During chronic inflammation, lymphangiogenesis promotes de novo formation of ectopic lymphoid tissue known as tertiary lymphoid organs (TLOs). These form during autoimmunity, microbial infection and chronic allograft rejection. TLOs share considerable morphological, cellular, chemokine and vascular characteristics with LNs. Chronic rejection of transplanted human kidneys is marked by a substantial increase in lymphatic vessel density within and surrounding immune cell infiltrates compared to organs that engraft well. ${ }^{99}$ Additionally, the rejection of corneal grafts can be predicted by the presence of lymphangiogenesis. ${ }^{100}$ In the synovium of rheumatoid arthritis patients, the lymphangiogenic factor VEGF-C is increased. ${ }^{101}$ Lymphangiogenesis has also been noted in other autoimmune pathologies such as inflammatory bowel diseases, Crohn's disease and ulcerative colitis, further highlighting the important role lymphatic vessels play in these immune processes. ${ }^{102}$ 


\section{LYMPHATIC METASTASIS}

Cancer cells invading the tumor margin enter enlarged lymphatics and travel with the lymph flow to the draining LNs (Figure 4). ${ }^{103}$ The growth of metastasizing tumors in LNs is a critical event in disease progression that profoundly impacts patient prognosis and treatment decisions. ${ }^{104,105}$ Cancer progression shares many features of wound healing and inflammatory conditions, including angiogenesis, ${ }^{64,82,94}$ lymphangiogenesis, ${ }^{106,} 107$ and immune cell recruitment. ${ }^{108,109}$ As such, tumors have been described as "wounds that do not heal." 110 These changes provide an expanded lymphatic network that enhances molecular and cellular delivery to the draining LN. Lymph flow from tumors has been reported to be elevated relative to normal tissue (Figure 4). This is due to the increased interstitial fluid pressure within the tumor mass, which is elevated as a result of the hyperpermeable tumor blood vasculature and the lack of lymphatic transport inside of tumors. Increases in interstitial flow have been positively correlated with cancer cell dissemination to the draining lymph node. ${ }^{111,112}$

Extensive studies utilizing molecular markers such as LYVE-1 and podoplanin have revealed the existence of lymphatic vessels within and around primary tumors. ${ }^{113-119}$ These studies have shown that secretion of VEGF-C and VEGF-D by tumor cells correlates with the development of tumor-associated lymphatic networks in numerous animal models. This corresponds with increases in vessel diameter, volumetric flow rate and cancer cell dissemination to LNs. ${ }^{103,115,116,118,120-125}$ Despite several observations of LEC proliferation within tumors, intratumoral lymphatic vessels are physically collapsed and non-functional. ${ }^{116,126}$ These observations collectively suggest that cancer cells disseminate by invading and utilizing lymphatic vessels within their margins. ${ }^{116,122}$ Moreover, functional lymphatics in the tumor periphery have been shown to exhibit abnormal draining patterns, indicative of dysfunctional valves in these vessels. ${ }^{125}$

Many human tumors do not show evidence of lymphangiogenesis within and around the tumor even though they commonly metastasize to LNs. Clinically, the correlation between VEGF-C/D expression in human tumors and metastatic spread is quite strong. It is therefore likely that VEGF-C/D expression by human tumors facilitates metastasis by priming existing lymphatic vessels in the tumor periphery and in the draining LN in addition to the generation of any new lymphatic vessels. ${ }^{127}$

Lymphangiogenesis has been observed within the tumor-draining LN prior to tumor seeding (Figure 4). The hypoxic microenvironment of the tumor causes the draining $\mathrm{LN}$ to become chronically inflamed. As a consequence, the draining $\mathrm{LN}$ is bathed in fluid from the tumor that consists of inflammatory mediators and tumor-secreted antigens, cytokines and growth factors. In the end, the tumor-draining LN is more immunologically tolerant of the invading cancer cells compared to a $\mathrm{LN}$ that does not drain the tumor. ${ }^{111}$

Multiple studies have shown that blocking VEGF-C or VEGF-D signaling reduces metastasis to the $\mathrm{LN}$, thus providing promising targets for therapies in lymphatic metastasis. ${ }^{103,121,122,128,129}$ Unfortunately, targeting VEGF-C/VEGFR-3 signaling in animal models works well to prevent $\mathrm{LN}$ metastasis but does not affect tumor growth once the tumor has seeded in the LN. This indicates that effective anti-VEGF-C/D treatments may be limited to the neoadjuvant or preventive settings. ${ }^{103,130}$

While anti-VEGF-C/VEGFR3 targeted therapies are still in their clinical infancy, antiangiogenic therapies that target VEGF-A have been pursued in human studies. VEGF-A, which promotes hematogenous metastasis by generating tumor blood vessels, also promotes lymphatic metastasis. ${ }^{122}$, 131, 132 While these promising new therapies that target VEGF-A have yielded a weaker impact on metastatic disease in the clinical when compared to results 
presented in animal model-based preclinical studies, they have shown tremendous promise in specific disease settings such as metastatic colon cancer. ${ }^{133}$ Some preclinical studies have put forth a provocative hypothesis that anti-VEGF therapies administered at high doses might promote metastasis. ${ }^{132,133}$ However, this has not been recapitulated in other preclinical studies or in recent clinical trials. ${ }^{130,134}$

\section{CONCLUSION}

Lymphatic vessels are pivotal to maintaining fluid balance, immune defense and uptake of dietary fats. Moreover, lymphatic vessels facilitate tumor metastasis. It has become increasingly clear that lymphatic vessels differ greatly from blood vessels structurally and in the molecular mechanisms that drive their function. Notably, transport of fluid is mediated by mechanisms intrinsic to the collecting lymphatic vessels themselves rather than by a centralized pump such as the heart. Cell signaling pathways that are relevant to lymphatic specification and function are being uncovered at a rapid rate. Better imaging techniques have allowed for real-time visualization of lymphatic pumping, tumor metastasis, immune function and characterization of various lymphatic phenotypes at cellular and subcellular levels. With the knowledge provided by these tools, key players such as FoxC 2 have been linked to lymphatic insufficiency and tissue edema. The role of lymphangiogenesis in the immune rejection of transplanted tissues has been characterized and novel treatments have been developed to address this issue. Moreover, secretion of lymphangiogenic growth factors such as VEGF-C by tumors has been connected to NO production, prostaglandin synthesis and dissemination of cancer cells to lymph nodes, linking it to lymphatic metastasis in animal models. Despite these advancements, numerous molecular pathways important to lymphatic (patho)physiology remain poorly understood. The fact that tumors invade draining lymph nodes has made understanding lymphatic physiology crucial to the development of new cancer treatments. Future investigations into how these numerous molecular pathways communicate with one another to regulate the many facets of lymphatic function will provide invaluable tools for the management of lymphatic-associated diseases.

\section{Acknowledgments}

The authors would like to thank Drs. Rakesh Jain, Dai Fukumura and Jay Loeffler for their critical input and support. The authors are supported by NIH R00CA137167, NIH DP2OD008780, NIH R21AI097745 and NCI Federal Share/Proton Beam Income (TPP), NIH R01HL106584 and NIH R01CA149285 (LLM), NIH T32CA073479 (CTK) and Charles King Trust Fellowship (SL).

\section{References}

1. Iqbal J, Hussain MM. Intestinal lipid absorption. Am J Physiol Endocrinol Metab. 2009; 296:E1183-1194. [PubMed: 19158321]

2. Wang Y, Oliver G. Current views on the function of the lymphatic vasculature in health and disease. Genes Dev. 2010; 24:2115-2126. [PubMed: 20889712]

3. Sebzda E, Hibbard C, Sweeney S, Abtahian F, Bezman N, Clemens G, Maltzman JS, Cheng L, Liu F, Turner M, et al. Syk and Slp-76 mutant mice reveal a cell-autonomous hematopoietic cell contribution to vascular development. Dev Cell. 2006; 11:349-361. [PubMed: 16950126]

4. Abtahian F, Guerriero A, Sebzda E, Lu MM, Zhou R, Mocsai A, Myers EE, Huang B, Jackson DG, Ferrari VA, et al. Regulation of blood and lymphatic vascular separation by signaling proteins SLP-76 and Syk. Science. 2003; 299:247-251. [PubMed: 12522250]

5. Wigle JT, Oliver G. Prox 1 function is required for the development of the murine lymphatic system. Cell. 1999; 98:769-778. [PubMed: 10499794]

6. Francois M, Caprini A, Hosking B, Orsenigo F, Wilhelm D, Browne C, Paavonen K, Karnezis T, Shayan R, Downes M, et al. Sox18 induces development of the lymphatic vasculature in mice. Nature. 2008; 456:643-647. [PubMed: 18931657] 
7. Lee S, Kang J, Yoo J, Ganesan SK, Cook SC, Aguilar B, Ramu S, Lee J, Hong YK. Prox1 physically and functionally interacts with COUP-TFII to specify lymphatic endothelial cell fate. Blood. 2009; 113:1856-1859. [PubMed: 18815287]

8. Gale NW, Prevo R, Espinosa J, Ferguson DJ, Dominguez MG, Yancopoulos GD, Thurston G, Jackson DG. Normal lymphatic development and function in mice deficient for the lymphatic hyaluronan receptor LYVE-1. Mol Cell Biol. 2007; 27:595-604. [PubMed: 17101772]

9. Sabine A, Agalarov Y, Maby-El Hajjami H, Jaquet M, Hagerling R, Pollmann C, Bebber D, Pfenniger A, Miura N, Dormond O, et al. Mechanotransduction, PROX1, and FOXC2 cooperate to control connexin37 and calcineurin during lymphatic-valve formation. Dev Cell. 2012; 22:430-445. [PubMed: 22306086]

10. Petrova TV, Karpanen T, Norrmen C, Mellor R, Tamakoshi T, Finegold D, Ferrell R, Kerjaschki D, Mortimer P, Yla-Herttuala S, et al. Defective valves and abnormal mural cell recruitment underlie lymphatic vascular failure in lymphedema distichiasis. Nat Med. 2004; 10:974-981. [PubMed: 15322537]

11. Ferrell RE. Research perspectives in inherited lymphatic disease. Ann N Y Acad Sci. 2002; 979:39-51. discussion 76-39. [PubMed: 12543715]

12. Karkkainen MJ, Haiko P, Sainio K, Partanen J, Taipale J, Petrova TV, Jeltsch M, Jackson DG, Talikka M, Rauvala H, et al. Vascular endothelial growth factor $\mathrm{C}$ is required for sprouting of the first lymphatic vessels from embryonic veins. Nat Immunol. 2004; 5:74-80. [PubMed: 14634646]

13. Breslin JW, Gaudreault N, Watson KD, Reynoso R, Yuan SY, Wu MH. Vascular endothelial growth factor-C stimulates the lymphatic pump by a VEGF receptor-3-dependent mechanism. Am J Physiol Heart Circ Physiol. 2007; 293:H709-718. [PubMed: 17400713]

14. Gale NW, Thurston G, Hackett SF, Renard R, Wang Q, McClain J, Martin C, Witte C, Witte MH, Jackson D, et al. Angiopoietin-2 is required for postnatal angiogenesis and lymphatic patterning, and only the latter role is rescued by Angiopoietin-1. Dev Cell. 2002; 3:411-423. [PubMed: 12361603]

15. Augustin HG, Koh GY, Thurston G, Alitalo K. Control of vascular morphogenesis and homeostasis through the angiopoietin-Tie system. Nat Rev Mol Cell Biol. 2009; 10:165-177. [PubMed: 19234476]

16. Kim KE, Cho CH, Kim HZ, Baluk P, McDonald DM, Koh GY. In vivo actions of angiopoietins on quiescent and remodeling blood and lymphatic vessels in mouse airways and skin. Arterioscler Thromb Vasc Biol. 2007; 27:564-570. [PubMed: 17194894]

17. Makinen T, Adams RH, Bailey J, Lu Q, Ziemiecki A, Alitalo K, Klein R, Wilkinson GA. PDZ interaction site in ephrinB2 is required for the remodeling of lymphatic vasculature. Genes Dev. 2005; 19:397-410. [PubMed: 15687262]

18. Maruyama K, Ii M, Cursiefen C, Jackson DG, Keino H, Tomita M, Van Rooijen N, Takenaka H, D'Amore PA, Stein-Streilein J, et al. Inflammation-induced lymphangiogenesis in the cornea arises from CD11b-positive macrophages. J Clin Invest. 2005; 115:2363-2372. [PubMed: 16138190]

19. Hamrah P, Chen L, Cursiefen C, Zhang Q, Joyce NC, Dana MR. Expression of vascular endothelial growth factor receptor-3 (VEGFR-3) on monocytic bone marrow-derived cells in the conjunctiva. Exp Eye Res. 2004; 79:553-561. [PubMed: 15381039]

20. Cursiefen C, Chen L, Borges LP, Jackson D, Cao J, Radziejewski C, D’Amore PA, Dana MR, Wiegand SJ, Streilein JW. VEGF-A stimulates lymphangiogenesis and hemangiogenesis in inflammatory neovascularization via macrophage recruitment. J Clin Invest. 2004; 113:10401050. [PubMed: 15057311]

21. Mimura T, Amano S, Usui T, Kaji Y, Oshika T, Ishii Y. Expression of vascular endothelial growth factor $\mathrm{C}$ and vascular endothelial growth factor receptor 3 in corneal lymphangiogenesis. Exp Eye Res. 2001; 72:71-78. [PubMed: 11133184]

22. Schoppmann SF, Birner P, Stockl J, Kalt R, Ullrich R, Caucig C, Kriehuber E, Nagy K, Alitalo K, Kerjaschki D. Tumor-associated macrophages express lymphatic endothelial growth factors and are related to peritumoral lymphangiogenesis. Am J Pathol. 2002; 161:947-956. [PubMed: 12213723] 
23. Skobe M, Hamberg LM, Hawighorst T, Schirner M, Wolf GL, Alitalo K, Detmar M. Concurrent induction of lymphangiogenesis, angiogenesis, and macrophage recruitment by vascular endothelial growth factor-C in melanoma. Am J Pathol. 2001; 159:893-903. [PubMed: 11549582]

24. Baluk P, Fuxe J, Hashizume H, Romano T, Lashnits E, Butz S, Vestweber D, Corada M, Molendini C, Dejana E, et al. Functionally specialized junctions between endothelial cells of lymphatic vessels. J Exp Med. 2007; 204:2349-2362. [PubMed: 17846148]

25. Yao LC, Baluk P, Srinivasan RS, Oliver G, McDonald DM. Plasticity of button-like junctions in the endothelium of airway lymphatics in development and inflammation. Am J Pathol. 2012; 180:2561-2575. [PubMed: 22538088]

26. Schmid-Schonbein GW. Microlymphatics and lymph flow. Physiol Rev. 1990; 70:987-1028. [PubMed: 2217560]

27. Johnston M, Zakharov A, Papaiconomou C, Salmasi G, Armstrong D. Evidence of connections between cerebrospinal fluid and nasal lymphatic vessels in humans, non-human primates and other mammalian species. Cerebrospinal Fluid Res. 2004; 1:2. [PubMed: 15679948]

28. Bridenbaugh EA, Gashev AA, Zawieja DC. Lymphatic muscle: a review of contractile function. Lymphat Res Biol. 2003; 1:147-158. [PubMed: 15624422]

29. von der Weid PY, Zawieja DC. Lymphatic smooth muscle: the motor unit of lymph drainage. Int J Biochem Cell Biol. 2004; 36:1147-1153. [PubMed: 15109561]

30. Liao S, Cheng G, Conner DA, Huang Y, Kucherlapati RS, Munn LL, Ruddle NH, Jain RK, Fukumura D, Padera TP. Impaired lymphatic contraction associated with immunosuppression. Proc Natl Acad Sci U S A. 2011; 108:18784-18789. [PubMed: 22065738]

31. Ohhashi T, Mizuno R, Ikomi F, Kawai Y. Current topics of physiology and pharmacology in the lymphatic system. Pharmacol Ther. 2005; 105:165-188. [PubMed: 15670625]

32. Mizuno R, Ono N, Ohhashi T. Involvement of ATP-sensitive $\mathrm{K}(+)$ channels in spontaneous activity of isolated lymph microvessels in rats. Am J Physiol. 1999; 277:H1453-1456. [PubMed: 10516182]

33. Gasheva OY, Zawieja DC, Gashev AA. Contraction-initiated NO-dependent lymphatic relaxation: a self-regulatory mechanism in rat thoracic duct. J Physiol. 2006; 575:821-832. [PubMed: 16809357]

34. Hagendoorn J, Padera TP, Kashiwagi S, Isaka N, Noda F, Lin MI, Huang PL, Sessa WC, Fukumura D, Jain RK. Endothelial nitric oxide synthase regulates microlymphatic flow via collecting lymphatics. Circ Res. 2004; 95:204-209. [PubMed: 15192027]

35. Lahdenranta J, Hagendoorn J, Padera TP, Hoshida T, Nelson G, Kashiwagi S, Jain RK, Fukumura D. Endothelial nitric oxide synthase mediates lymphangiogenesis and lymphatic metastasis. Cancer Res. 2009; 69:2801-2808. [PubMed: 19318557]

36. Bohlen HG, Wang W, Gashev A, Gasheva O, Zawieja D. Phasic contractions of rat mesenteric lymphatics increase basal and phasic nitric oxide generation in vivo. Am J Physiol Heart Circ Physiol. 2009; 297:H1319-1328. [PubMed: 19666850]

37. Bohlen HG, Gasheva OY, Zawieja DC. Nitric oxide formation by lymphatic bulb and valves is a major regulatory component of lymphatic pumping. Am J Physiol Heart Circ Physiol. 2011; 301:H1897-1906. [PubMed: 21890688]

38. Eisenhoffer J, Yuan ZY, Johnston MG. Evidence that the L-arginine pathway plays a role in the regulation of pumping activity in bovine mesenteric lymphatic vessels. Microvasc Res. 1995; 50:249-259. [PubMed: 8538504]

39. Koller A, Mizuno R, Kaley G. Flow reduces the amplitude and increases the frequency of lymphatic vasomotion: role of endothelial prostanoids. Am J Physiol. 1999; 277:R1683-1689. [PubMed: 10600914]

40. Shirasawa Y, Ikomi F, Ohhashi T. Physiological roles of endogenous nitric oxide in lymphatic pump activity of rat mesentery in vivo. Am J Physiol Gastrointest Liver Physiol. 2000; 278:G551556. [PubMed: 10762608]

41. Fukumura D, Kashiwagi S, Jain RK. The role of nitric oxide in tumour progression. Nat Rev Cancer. 2006; 6:521-534. [PubMed: 16794635] 
42. Kashiwagi S, Tsukada K, Xu L, Miyazaki J, Kozin SV, Tyrrell JA, Sessa WC, Gerweck LE, Jain RK, Fukumura D. Perivascular nitric oxide gradients normalize tumor vasculature. Nat Med. 2008; 14:255-257. [PubMed: 18278052]

43. Kunert, C.; Padera, TP.; Munn, LL. Lattic Boltzmann simulations of lymphatic pumping. American Physical Society; Boston, MA: 2012. http://meetings.aps.org/link/BAPS. 2012.MAR.D42.2

44. Gashev AA, Davis MJ, Zawieja DC. Inhibition of the active lymph pump by flow in rat mesenteric lymphatics and thoracic duct. J Physiol. 2002; 540:1023-1037. [PubMed: 11986387]

45. Tsunemoto H, Ikomi F, Ohhashi T. Flow-mediated release of nitric oxide from lymphatic endothelial cells of pressurized canine thoracic duct. Jpn J Physiol. 2003; 53:157-163. [PubMed: 14529576]

46. von der Weid PY, Crowe MJ, Van Helden DF. Endothelium-dependent modulation of pacemaking in lymphatic vessels of the guinea-pig mesentery. J Physiol. 1996; 493 ( Pt 2):563-575. [PubMed: 8782117]

47. Li X, Mizuno R, Ono N, Ohhashi T. Glucose and glucose transporters regulate lymphatic pump activity through activation of the mitochondrial ATP-sensitive K+ channel. J Physiol Sci. 2008; 58:249-261. [PubMed: 18597699]

48. Johnston MG, Feuer C. Suppression of lymphatic vessel contractility with inhibitors of arachidonic acid metabolism. J Pharmacol Exp Ther. 1983; 226:603-607. [PubMed: 6410049]

49. Johnston MG, Gordon JL. Regulation of lymphatic contractility by arachidonate metabolites. Nature. 1981; 293:294-297. [PubMed: 7196995]

50. Ohhashi T, Azuma T. Variegated effects of prostaglandins on spontaneous activity in bovine mesenteric lymphatics. Microvasc Res. 1984; 27:71-80. [PubMed: 6143241]

51. Arunlakshana O, Schild HO. Some quantitative uses of drug antagonists. Br J Pharmacol Chemother. 1959; 14:48-58. [PubMed: 13651579]

52. Ohhashi T, Takahashi N. Acetylcholine-induced release of endothelium-derived relaxing factor from lymphatic endothelial cells. Am J Physiol. 1991; 260:H1172-1178. [PubMed: 2012221]

53. Chan AK, von der Weid PY. 5-HT decreases contractile and electrical activities in lymphatic vessels of the guinea-pig mesentery: role of 5-HT 7-receptors. Br J Pharmacol. 2003; 139:243254. [PubMed: 12770929]

54. Fox JL, von der Weid PY. Effects of histamine on the contractile and electrical activity in isolated lymphatic vessels of the guinea-pig mesentery. Br J Pharmacol. 2002; 136:1210-1218. [PubMed: 12163355]

55. Wang H. Activated macrophage-mediated endogenous prostaglandin and nitric oxide-dependent relaxation of lymphatic smooth muscles. Jpn J Physiol. 1997; 47:93-100. [PubMed: 9159648]

56. Arai F, Mizuno R, Ohhashi T. Effects of VEGF on $\mathrm{Ca}(2+)$-transient in cultured lymphatic endothelial cells and mechanical activity of isolated lymph vessels. Jpn J Physiol. 2000; 50:343355. [PubMed: 11016985]

57. Hosaka K, Mizuno R, Ohhashi T. Rho-Rho kinase pathway is involved in the regulation of myogenic tone and pump activity in isolated lymph vessels. Am J Physiol Heart Circ Physiol. 2003; 284:H2015-2025. [PubMed: 12742825]

58. Hangai-Hoger N, Cabrales P, Briceno JC, Tsai AG, Intaglietta M. Microlymphatic and tissue oxygen tension in the rat mesentery. Am J Physiol Heart Circ Physiol. 2004; 286:H878-883. [PubMed: 14630627]

59. Mackay CR, Marston WL, Dudler L. Naive and memory T cells show distinct pathways of lymphocyte recirculation. J Exp Med. 1990; 171:801-817. [PubMed: 2307933]

60. Pugh CW, MacPherson GG, Steer HW. Characterization of nonlymphoid cells derived from rat peripheral lymph. J Exp Med. 1983; 157:1758-1779. [PubMed: 6854208]

61. Lee JW, Epardaud M, Sun J, Becker JE, Cheng AC, Yonekura AR, Heath JK, Turley SJ. Peripheral antigen display by lymph node stroma promotes $\mathrm{T}$ cell tolerance to intestinal self. Nat Immunol. 2007; 8:181-190. [PubMed: 17195844]

62. Nichols LA, Chen Y, Colella TA, Bennett CL, Clausen BE, Engelhard VH. Deletional selftolerance to a melanocyte/melanoma antigen derived from tyrosinase is mediated by a radio-

Wiley Interdiscip Rev Syst Biol Med. Author manuscript; available in PMC 2014 January 01. 
resistant cell in peripheral and mesenteric lymph nodes. J Immunol. 2007; 179:993-1003. [PubMed: 17617591]

63. Cohen JN, Guidi CJ, Tewalt EF, Qiao H, Rouhani SJ, Ruddell A, Farr AG, Tung KS, Engelhard VH. Lymph node-resident lymphatic endothelial cells mediate peripheral tolerance via Aireindependent direct antigen presentation. J Exp Med. 2010; 207:681-688. [PubMed: 20308365]

64. Liao S, Ruddle NH. Synchrony of high endothelial venules and lymphatic vessels revealed by immunization. J Immunol. 2006; 177:3369-3379. [PubMed: 16920978]

65. Mebius RE, Dowbenko D, Williams A, Fennie C, Lasky LA, Watson SR. Expression of GlyCAM-1, an endothelial ligand for L-selectin, is affected by afferent lymphatic flow. J Immunol. 1993; 151:6769-6776. [PubMed: 7505014]

66. Mebius RE, Streeter PR, Breve J, Duijvestijn AM, Kraal G. The influence of afferent lymphatic vessel interruption on vascular addressin expression. J Cell Biol. 1991; 115:85-95. [PubMed: 1918141]

67. Drayton DL, Liao S, Mounzer RH, Ruddle NH. Lymphoid organ development: from ontogeny to neogenesis. Nat Immunol. 2006; 7:344-353. [PubMed: 16550197]

68. Cyster JG. Chemokines, sphingosine-1-phosphate, and cell migration in secondary lymphoid organs. Annu Rev Immunol. 2005; 23:127-159. [PubMed: 15771568]

69. Lo CG, Xu Y, Proia RL, Cyster JG. Cyclical modulation of sphingosine-1-phosphate receptor 1 surface expression during lymphocyte recirculation and relationship to lymphoid organ transit. J Exp Med. 2005; 201:291-301. [PubMed: 15657295]

70. von Andrian UH, M'Rini C. In situ analysis of lymphocyte migration to lymph nodes. Cell Adhes Commun. 1998; 6:85-96. [PubMed: 9823458]

71. Anderson AO, Anderson ND. Studies on the structure and permeability of the microvasculature in normal rat lymph nodes. Am J Pathol. 1975; 80:387-418. [PubMed: 1163637]

72. Gretz JE, Anderson AO, Shaw S. Cords, channels, corridors and conduits: critical architectural elements facilitating cell interactions in the lymph node cortex. Immunol Rev. 1997; 156:11-24. [PubMed: 9176696]

73. Gretz JE, Kaldjian EP, Anderson AO, Shaw S. Sophisticated strategies for information encounter in the lymph node: the reticular network as a conduit of soluble information and a highway for cell traffic. J Immunol. 1996; 157:495-499. [PubMed: 8752893]

74. Gretz JE, Norbury CC, Anderson AO, Proudfoot AE, Shaw S. Lymph-borne chemokines and other low molecular weight molecules reach high endothelial venules via specialized conduits while a functional barrier limits access to the lymphocyte microenvironments in lymph node cortex. J Exp Med. 2000; 192:1425-1440. [PubMed: 11085745]

75. Iannacone M, Moseman EA, Tonti E, Bosurgi L, Junt T, Henrickson SE, Whelan SP, Guidotti LG, von Andrian UH. Subcapsular sinus macrophages prevent CNS invasion on peripheral infection with a neurotropic virus. Nature. 2010; 465:1079-1083. [PubMed: 20577213]

76. Roozendaal R, Mempel TR, Pitcher LA, Gonzalez SF, Verschoor A, Mebius RE, von Andrian UH, Carroll MC. Conduits mediate transport of low-molecular-weight antigen to lymph node follicles. Immunity. 2009; 30:264-276. [PubMed: 19185517]

77. Phan TG, Green JA, Gray EE, Xu Y, Cyster JG. Immune complex relay by subcapsular sinus macrophages and noncognate B cells drives antibody affinity maturation. Nat Immunol. 2009; 10:786-793. [PubMed: 19503106]

78. Mempel TR, Henrickson SE, Von Andrian UH. T-cell priming by dendritic cells in lymph nodes occurs in three distinct phases. Nature. 2004; 427:154-159. [PubMed: 14712275]

79. Schumann K, Lammermann T, Bruckner M, Legler DF, Polleux J, Spatz JP, Schuler G, Forster R, Lutz MB, Sorokin L, et al. Immobilized chemokine fields and soluble chemokine gradients cooperatively shape migration patterns of dendritic cells. Immunity. 2010; 32:703-713. [PubMed: 20471289]

80. Randolph GJ, Angeli V, Swartz MA. Dendritic-cell trafficking to lymph nodes through lymphatic vessels. Nat Rev Immunol. 2005; 5:617-628. [PubMed: 16056255]

81. Braun A, Worbs T, Moschovakis GL, Halle S, Hoffmann K, Bolter J, Munk A, Forster R. Afferent lymph-derived T cells and DCs use different chemokine receptor CCR7-dependent routes for entry

Wiley Interdiscip Rev Syst Biol Med. Author manuscript; available in PMC 2014 January 01. 
into the lymph node and intranodal migration. Nat Immunol. 2011; 12:879-887. [PubMed: 21841786]

82. Halin C, Tobler NE, Vigl B, Brown LF, Detmar M. VEGF-A produced by chronically inflamed tissue induces lymphangiogenesis in draining lymph nodes. Blood. 2007; 110:3158-3167. [PubMed: 17625067]

83. Swarte VV, Joziasse DH, Van den Eijnden DH, Petryniak B, Lowe JB, Kraal G, Mebius RE. Regulation of fucosyltransferase-VII expression in peripheral lymph node high endothelial venules. Eur J Immunol. 1998; 28:3040-3047. [PubMed: 9808172]

84. Hoke D, Mebius RE, Dybdal N, Dowbenko D, Gribling P, Kyle C, Baumhueter S, Watson SR. Selective modulation of the expression of L-selectin ligands by an immune response. Curr Biol. 1995; 5:670-678. [PubMed: 7552178]

85. Mebius RE, Breve J, Duijvestijn AM, Kraal G. The function of high endothelial venules in mouse lymph nodes stimulated by oxazolone. Immunology. 1990; 71:423-427. [PubMed: 2269478]

86. Mueller SN, Hosiawa-Meagher KA, Konieczny BT, Sullivan BM, Bachmann MF, Locksley RM, Ahmed R, Matloubian M. Regulation of homeostatic chemokine expression and cell trafficking during immune responses. Science. 2007; 317:670-674. [PubMed: 17673664]

87. Fletcher AL, Lukacs-Kornek V, Reynoso ED, Pinner SE, Bellemare-Pelletier A, Curry MS, Collier AR, Boyd RL, Turley SJ. Lymph node fibroblastic reticular cells directly present peripheral tissue antigen under steady-state and inflammatory conditions. J Exp Med. 2010; 207:689-697. [PubMed: 20308362]

88. Mallon EC, Ryan TJ. Lymphedema and wound healing. Clin Dermatol. 1994; 12:89-93. [PubMed: 8180949]

89. Witte CL, Witte MH. Disorders of lymph flow. Acad Radiol. 1995; 2:324-334. [PubMed: 9419570]

90. Golshan M, Smith B. Prevention and management of arm lymphedema in the patient with breast cancer. J Support Oncol. 2006; 4:381-386. [PubMed: 17004511]

91. Morrell RM, Halyard MY, Schild SE, Ali MS, Gunderson LL, Pockaj BA. Breast cancer-related lymphedema. Mayo Clin Proc. 2005; 80:1480-1484. [PubMed: 16295027]

92. Szuba A, Rockson SG. Lymphedema: anatomy, physiology and pathogenesis. Vasc Med. 1997; 2:321-326. [PubMed: 9575606]

93. Alitalo K, Tammela T, Petrova TV. Lymphangiogenesis in development and human disease. Nature. 2005; 438:946-953. [PubMed: 16355212]

94. Angeli V, Ginhoux F, Llodra J, Quemeneur L, Frenette PS, Skobe M, Jessberger R, Merad M, Randolph GJ. B cell-driven lymphangiogenesis in inflamed lymph nodes enhances dendritic cell mobilization. Immunity. 2006; 24:203-215. [PubMed: 16473832]

95. Jeon BH, Jang C, Han J, Kataru RP, Piao L, Jung K, Cha HJ, Schwendener RA, Jang KY, Kim KS, et al. Profound but dysfunctional lymphangiogenesis via vascular endothelial growth factor ligands from CD11b+ macrophages in advanced ovarian cancer. Cancer Res. 2008; 68:1100-1109. [PubMed: 18281485]

96. Kataru RP, Jung K, Jang C, Yang H, Schwendener RA, Baik JE, Han SH, Alitalo K, Koh GY. Critical role of CD11b+ macrophages and VEGF in inflammatory lymphangiogenesis, antigen clearance, and inflammation resolution. Blood. 2009; 113:5650-5659. [PubMed: 19346498]

97. Kim KE, Koh YJ, Jeon BH, Jang C, Han J, Kataru RP, Schwendener RA, Kim JM, Koh GY. Role of CD11b+ macrophages in intraperitoneal lipopolysaccharide-induced aberrant lymphangiogenesis and lymphatic function in the diaphragm. Am J Pathol. 2009; 175:1733-1745. [PubMed: 19762711]

98. Vigl B, Aebischer D, Nitschke M, Iolyeva M, Rothlin T, Antsiferova O, Halin C. Tissue inflammation modulates gene expression of lymphatic endothelial cells and dendritic cell migration in a stimulus-dependent manner. Blood. 2011; 118:205-215. [PubMed: 21596851]

99. Kerjaschki D, Huttary N, Raab I, Regele H, Bojarski-Nagy K, Bartel G, Krober SM, Greinix H, Rosenmaier A, Karlhofer F, et al. Lymphatic endothelial progenitor cells contribute to de novo lymphangiogenesis in human renal transplants. Nat Med. 2006; 12:230-234. [PubMed: 16415878]

Wiley Interdiscip Rev Syst Biol Med. Author manuscript; available in PMC 2014 January 01. 
100. Dietrich T, Bock F, Yuen D, Hos D, Bachmann BO, Zahn G, Wiegand S, Chen L, Cursiefen C. Cutting edge: lymphatic vessels, not blood vessels, primarily mediate immune rejections after transplantation. J Immunol. 2010; 184:535-539. [PubMed: 20018627]

101. Paavonen K, Mandelin J, Partanen T, Jussila L, Li TF, Ristimaki A, Alitalo K, Konttinen YT. Vascular endothelial growth factors $\mathrm{C}$ and D and their VEGFR-2 and 3 receptors in blood and lymphatic vessels in healthy and arthritic synovium. J Rheumatol. 2002; 29:39-45. [PubMed: 11824969]

102. von der Weid PY, Rainey KJ. Review article: lymphatic system and associated adipose tissue in the development of inflammatory bowel disease. Aliment Pharmacol Ther. 2010; 32:697-711. [PubMed: 20636483]

103. Hoshida T, Isaka N, Hagendoorn J, di Tomaso E, Chen YL, Pytowski B, Fukumura D, Padera TP, Jain RK. Imaging steps of lymphatic metastasis reveals that vascular endothelial growth factor-C increases metastasis by increasing delivery of cancer cells to lymph nodes: therapeutic implications. Cancer Res. 2006; 66:8065-8075. [PubMed: 16912183]

104. Veronesi U, Paganelli G, Viale G, Luini A, Zurrida S, Galimberti V, Intra M, Veronesi P, Robertson C, Maisonneuve $\mathrm{P}$, et al. A randomized comparison of sentinel-node biopsy with routine axillary dissection in breast cancer. N Engl J Med. 2003; 349:546-553. [PubMed: 12904519]

105. Morton DL, Thompson JF, Cochran AJ, Mozzillo N, Elashoff R, Essner R, Nieweg OE, Roses DF, Hoekstra HJ, Karakousis CP, et al. Sentinel-node biopsy or nodal observation in melanoma. N Engl J Med. 2006; 355:1307-1317. [PubMed: 17005948]

106. Mumprecht V, Honer M, Vigl B, Proulx ST, Trachsel E, Kaspar M, Banziger-Tobler NE, Schibli R, Neri D, Detmar M. In vivo imaging of inflammation- and tumor-induced lymph node lymphangiogenesis by immuno-positron emission tomography. Cancer Res. 2010; 70:88428851. [PubMed: 20978206]

107. Qian CN, Berghuis B, Tsarfaty G, Bruch M, Kort EJ, Ditlev J, Tsarfaty I, Hudson E, Jackson DG, Petillo D, et al. Preparing the "soil": the primary tumor induces vasculature reorganization in the sentinel lymph node before the arrival of metastatic cancer cells. Cancer Res. 2006; 66:1036510376. [PubMed: 17062557]

108. Gabrilovich DI, Nagaraj S. Myeloid-derived suppressor cells as regulators of the immune system. Nat Rev Immunol. 2009; 9:162-174. [PubMed: 19197294]

109. Murdoch C, Muthana M, Coffelt SB, Lewis CE. The role of myeloid cells in the promotion of tumour angiogenesis. Nat Rev Cancer. 2008; 8:618-631. [PubMed: 18633355]

110. Dvorak HF. Tumors: wounds that do not heal. Similarities between tumor stroma generation and wound healing. N Engl J Med. 1986; 315:1650-1659. [PubMed: 3537791]

111. Swartz MA, Lund AW. Lymphatic and interstitial flow in the tumour microenvironment: linking mechanobiology with immunity. Nat Rev Cancer. 2012; 12:210-219. [PubMed: 22362216]

112. Jain RK, Tong RT, Munn LL. Effect of vascular normalization by antiangiogenic therapy on interstitial hypertension, peritumor edema, and lymphatic metastasis: insights from a mathematical model. Cancer Res. 2007; 67:2729-2735. [PubMed: 17363594]

113. Pepper MS. Lymphangiogenesis and tumor metastasis: myth or reality? Clin Cancer Res. 2001; 7:462-468. [PubMed: 11297234]

114. Jain RK, Fenton BT. Intratumoral lymphatic vessels: a case of mistaken identity or malfunction? J Natl Cancer Inst. 2002; 94:417-421. [PubMed: 11904313]

115. Skobe M, Hawighorst T, Jackson DG, Prevo R, Janes L, Velasco P, Riccardi L, Alitalo K, Claffey $\mathrm{K}$, Detmar M. Induction of tumor lymphangiogenesis by VEGF-C promotes breast cancer metastasis. Nat Med. 2001; 7:192-198. [PubMed: 11175850]

116. Padera TP, Kadambi A, di Tomaso E, Carreira CM, Brown EB, Boucher Y, Choi NC, Mathisen D, Wain J, Mark EJ, et al. Lymphatic metastasis in the absence of functional intratumor lymphatics. Science. 2002; 296:1883-1886. [PubMed: 11976409]

117. Raica M, Cimpean AM, Ribatti D. The role of podoplanin in tumor progression and metastasis. Anticancer Res. 2008; 28:2997-3006. [PubMed: 19031946]

118. Karnezis T, Shayan R, Caesar C, Roufail S, Harris NC, Ardipradja K, Zhang YF, Williams SP, Farnsworth RH, Chai MG, et al. VEGF-D promotes tumor metastasis by regulating 
prostaglandins produced by the collecting lymphatic endothelium. Cancer Cell. 2012; 21:181195. [PubMed: 22340592]

119. Leu AJ, Berk DA, Lymboussaki A, Alitalo K, Jain RK. Absence of functional lymphatics within a murine sarcoma: a molecular and functional evaluation. Cancer Res. 2000; 60:4324-4327. [PubMed: 10969769]

120. Mandriota SJ, Jussila L, Jeltsch M, Compagni A, Baetens D, Prevo R, Banerji S, Huarte J, Montesano R, Jackson DG, et al. Vascular endothelial growth factor-C-mediated lymphangiogenesis promotes tumour metastasis. EMBO J. 2001; 20:672-682. [PubMed: 11179212]

121. Karpanen T, Egeblad M, Karkkainen MJ, Kubo H, Yla-Herttuala S, Jaattela M, Alitalo K. Vascular endothelial growth factor $\mathrm{C}$ promotes tumor lymphangiogenesis and intralymphatic tumor growth. Cancer Res. 2001; 61:1786-1790. [PubMed: 11280723]

122. Wong SY, Haack H, Crowley D, Barry M, Bronson RT, Hynes RO. Tumor-secreted vascular endothelial growth factor-C is necessary for prostate cancer lymphangiogenesis, but lymphangiogenesis is unnecessary for lymph node metastasis. Cancer Res. 2005; 65:9789-9798. [PubMed: 16267000]

123. Achen MG, Williams RA, Minekus MP, Thornton GE, Stenvers K, Rogers PA, Lederman F, Roufail S, Stacker SA. Localization of vascular endothelial growth factor-D in malignant melanoma suggests a role in tumour angiogenesis. J Pathol. 2001; 193:147-154. [PubMed: 11180159]

124. Stacker SA, Caesar C, Baldwin ME, Thornton GE, Williams RA, Prevo R, Jackson DG, Nishikawa S, Kubo H, Achen MG. VEGF-D promotes the metastatic spread of tumor cells via the lymphatics. Nat Med. 2001; 7:186-191. [PubMed: 11175849]

125. Isaka N, Padera TP, Hagendoorn J, Fukumura D, Jain RK. Peritumor lymphatics induced by vascular endothelial growth factor-C exhibit abnormal function. Cancer Res. 2004; 64:44004404. [PubMed: 15231646]

126. Padera TP, Stoll BR, Tooredman JB, Capen D, di Tomaso E, Jain RK. Pathology: cancer cells compress intratumour vessels. Nature. 2004; 427:695. [PubMed: 14973470]

127. Nisato RE, Tille JC, Pepper MS. Lymphangiogenesis and tumor metastasis. Thromb Haemost. 2003; 90:591-597. [PubMed: 14515178]

128. Achen MG, Stacker SA. Molecular control of lymphatic metastasis. Ann N Y Acad Sci. 2008; 1131:225-234. [PubMed: 18519975]

129. Achen MG, Mann GB, Stacker SA. Targeting lymphangiogenesis to prevent tumour metastasis. Br J Cancer. 2006; 94:1355-1360. [PubMed: 16641900]

130. Padera TP, Kuo AH, Hoshida T, Liao S, Lobo J, Kozak KR, Fukumura D, Jain RK. Differential response of primary tumor versus lymphatic metastasis to VEGFR-2 and VEGFR-3 kinase inhibitors cediranib and vandetanib. Mol Cancer Ther. 2008; 7:2272-2279. [PubMed: 18687659]

131. Hirakawa S, Kodama S, Kunstfeld R, Kajiya K, Brown LF, Detmar M. VEGF-A induces tumor and sentinel lymph node lymphangiogenesis and promotes lymphatic metastasis. J Exp Med. 2005; 201:1089-1099. [PubMed: 15809353]

132. Paez-Ribes M, Allen E, Hudock J, Takeda T, Okuyama H, Vinals F, Inoue M, Bergers G, Hanahan D, Casanovas O. Antiangiogenic therapy elicits malignant progression of tumors to increased local invasion and distant metastasis. Cancer Cell. 2009; 15:220-231. [PubMed: 19249680]

133. Ebos JM, Kerbel RS. Antiangiogenic therapy: impact on invasion, disease progression, and metastasis. Nat Rev Clin Oncol. 2011; 8:210-221. [PubMed: 21364524]

134. Allegra CJ, Yothers G, O’Connell MJ, Sharif S, Petrelli NJ, Colangelo LH, Atkins JN, Seay TE, Fehrenbacher L, Goldberg RM, et al. Phase III trial assessing bevacizumab in stages II and III carcinoma of the colon: results of NSABP protocol C-08. J Clin Oncol. 2011; 29:11-16. [PubMed: 20940184] 

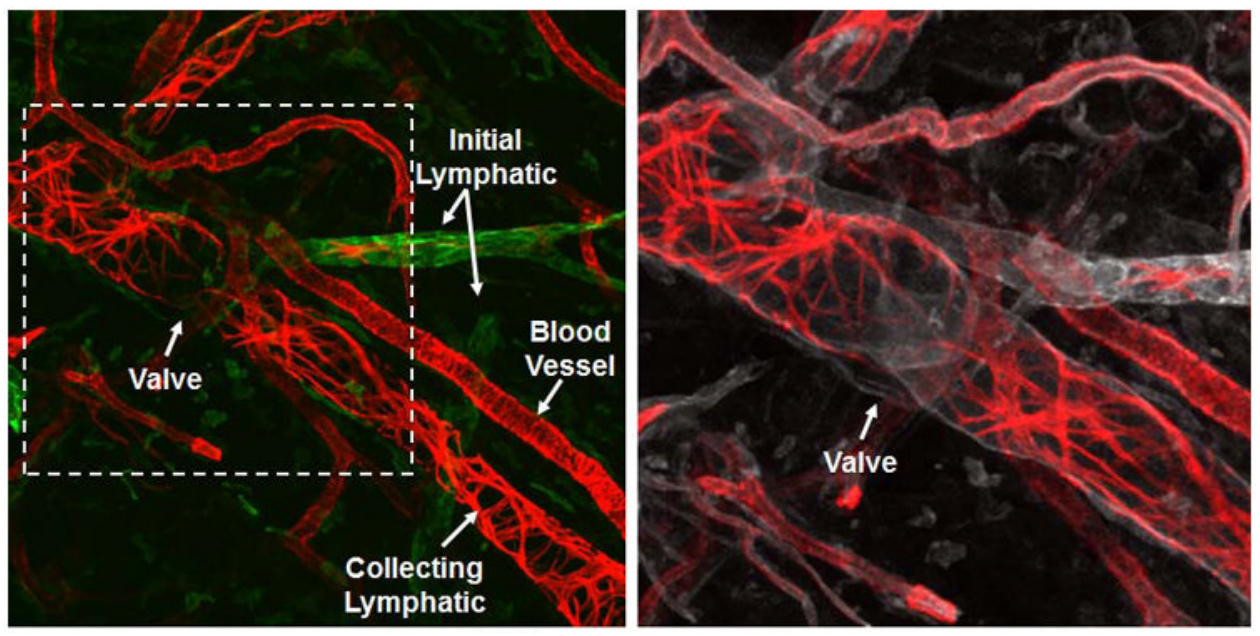

FIGURE 1. Initial and Collecting Lymphatics

The lymphatic vessels of the ear of an athymic nude mouse are shown. LYVE-1 (green) indicates the initial lymphatic vessels. aSMA (red) indicates the SMCs of the collecting lymphatic vessels and blood vessels. The circumferential aSMA staining pattern of the collecting lymphatic vessels is distinct from the more homogenous pattern of the blood vessels. CD31 (white) indicates all endothelial cells in the field and shows an intraluminal valve in the collecting lymphatic vessel. 


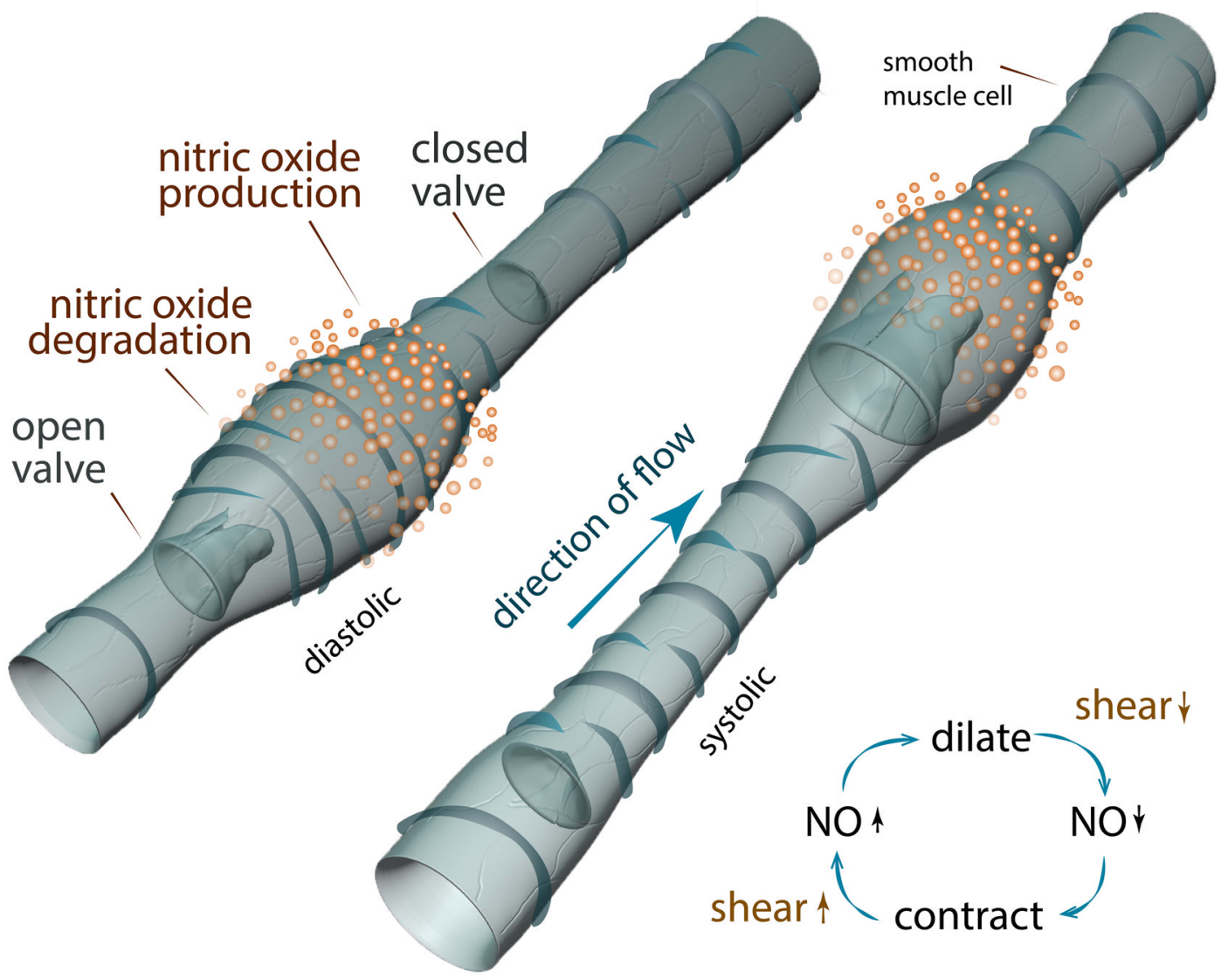

FIGURE 2. Lymphatic Contraction

This illustration of the diastolic and systolic phases of an autonomous lymphatic contraction shows the NO dependency. In the diastolic phase, local NO release allows for the relaxation of the vessel wall and filling to occur. As the NO degrades, the vessel constricts, driving flow into the next lymphangion. It is hypothesized that the increase in flow and shear stress as a result of a contraction, stimulates NO production, allowing the diastolic filling to occur. The spatial and temporal gradients of NO are critical to proper contraction function and are mediated by eNOS in LECs. 


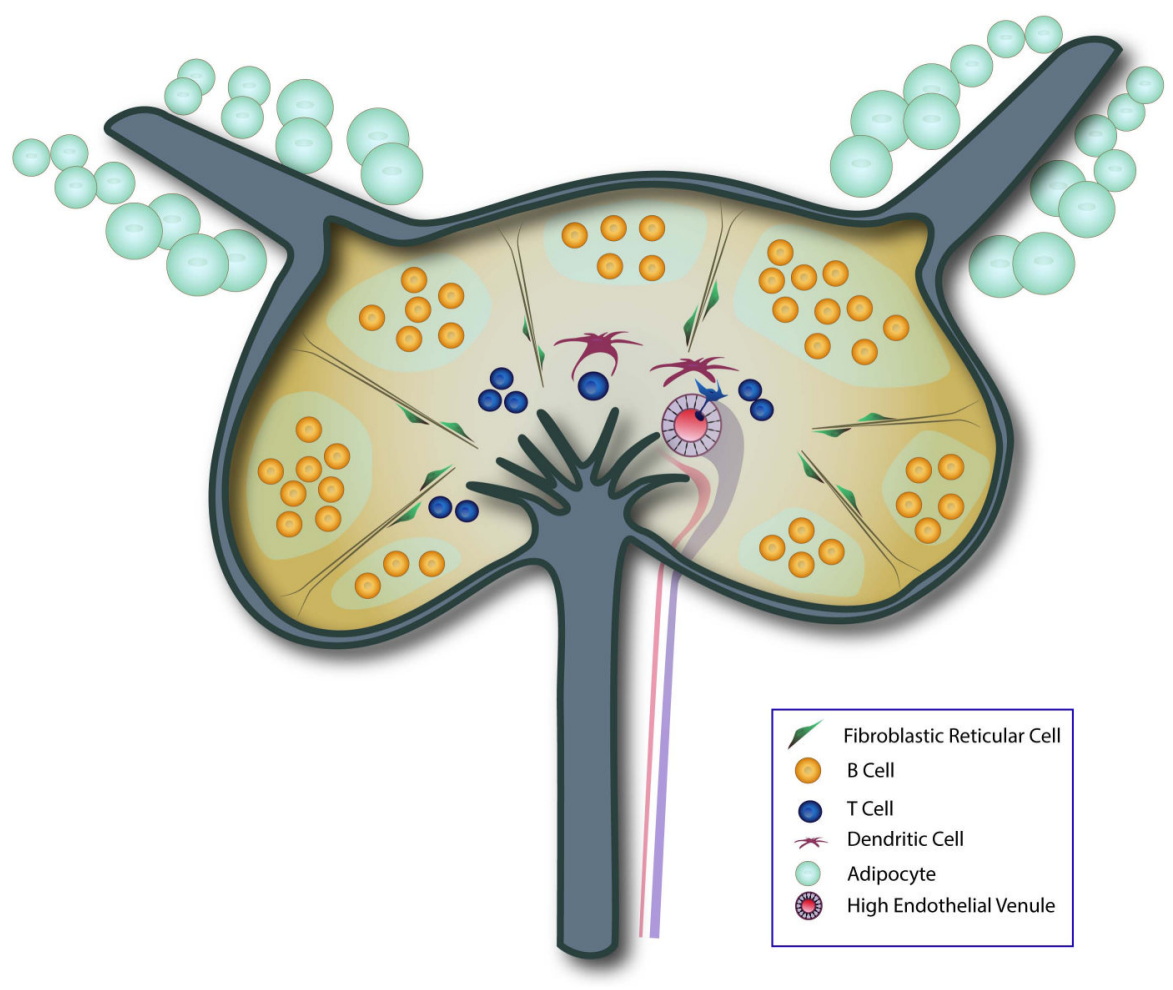

FIGURE 3. Microarchitecture of the Lymph Node

This simplified schematic of the lymph node highlights key structural features critical for the proper activation of an immune response. The adipose-encased afferent collecting lymphatic vessels move antigen-rich lymph into the subcapsular sinus. Fluid and small antigens can then filter into the lymph node cortex, where B cell follicles are found. Reticular fibers, bound by their associated FRCs and specialized DCs, traverse the cortex to rapidly bring antigen to the paracortical and medullary regions where T cells reside. HEVs in the paracortical area bring naïve T cells into the node as well to interact with DCs. In the medulla, there are lymphatic vessels that drain the lymph node and collect fluid into the efferent lymphatic vessel. 


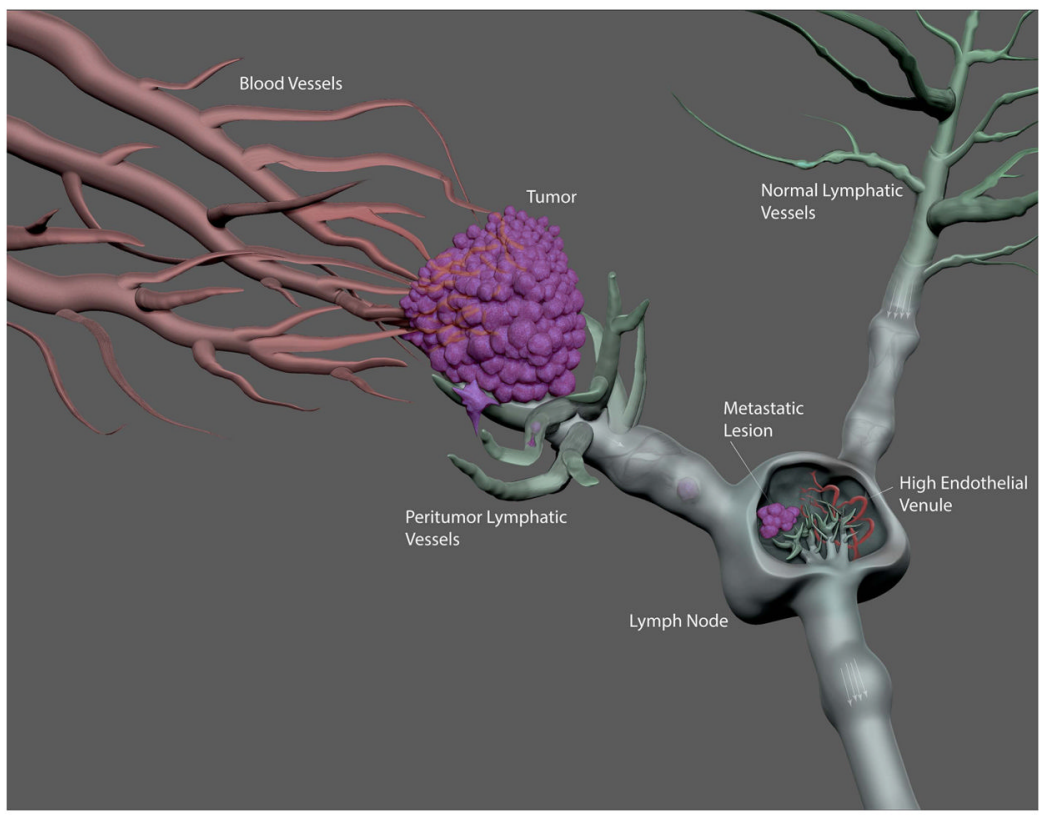

FIGURE 4. Components of Lymphatic Metastasis

In contrast to functional blood vessels that can be found throughout the tumor, functional lymphatic vessels are found in the margin of tumors. These tumor margin lymphatic vessels tend to be enlarged and have greater lymph flow compared to lymphatic vessels draining normal tissues. These functional lymphatics are penetrated by invading cancer cells, which travel to the draining lymph node where they evade the immune system and start to form a secondary metastatic tumor. Understanding the growth of the cancer cells in the lymph node is critical to the development of effective treatment for these metastatic lesions. 